\title{
IMPLEMENTASI MODUL PELATIHAN PENCEGAHAN DAN PENANGGULANGAN OBESITAS UNTUK GURU UKS DAN PETUGAS KESEHATAN DI PUSKESMAS SISIR KOTA BATU
}

\author{
Juin Hadisuyitno ${ }^{1}$, B. Doddy Riyadi ${ }^{2}$, I Komang Suwita ${ }^{3}$ \\ 1.2.3. Jurusan Gizi, Poltekkes Kemenkes Malang \\ juinhadi@gmail.com
}

\begin{abstract}
Overweight and obesity are now a health problem in society. The role of stakeholder, especially in educational institutions, namely the Usaha Kesehatan Sekolah (UKS) in the obesity prevention and prevention program is very necessary from the beginning, namely the school period. The obesity prevention and prevention training program for health workers and UKS coaches has never been done by the Puskesmas Sisir. The purpose of this activity is to improve the knowledge and skills of teachers and health workers in the prevention and control of obesity and obesity in elementary school children. The method of training with lectures, demonstrations and practices can increase participants' nutritional knowledge from an average score of 51.7 to 83.4 and make the skills in measuring height and weight gain be better and more correct. The sustainability of this activity must involve the participation and commitment of various stakeholder as well as the activity of Puskesmas staff. Activities at school will be effective by involving teachers and students and also training students to be able to carry out these activities independently.
\end{abstract}

Keywords: obesity, training, school children

\section{PENDAHULUAN}

Kegemukan dan obesitas terjadi akibat asupan energi lebih tinggi daripada energi yang dikeluarkan. Asupan energi tinggi disebabkan oleh konsumsi makanan sumber energi dan lemak tinggi, sedangkan pengeluaran energi yang rendah disebabkan karena kurangnya aktivitas fisik dan sedentary life style. (Kemenkes, 2012)

Obesitas merupakan masalah kesehatan bagi anak karena dapat meningkatkan resiko terjadinya penyakit jantung dan pembuluh darah, tekanan darah tinggi, diabetes melitus tipe 2, gangguan kesuburan. Obesitas pada anak juga dapat menjadikan penyebab kegemukan pada usia dewasa. (Andy Japutra dkk, 2015). Obesitas pada remaja di kawasan Asia Pasifik berhubungan dengan diabetes tipe 2 pada umur yang lebih muda. (Sri Poedji H.D dkk, 2017).

Kegemukan dan obesitas saat ini menjadi masalah kesehatan sebagian negara maju maupun berkembang. Masalah kegemukan tidak hanya dialami oleh Indonesia saja tetapi juga dialami oleh negara-negara di kawasan Asia Pasifik dan ditemukan tidak hanya pada penduduk dewasa akan tetapi juga pada anak-anak dan remaja. (Suiraoka, 2015)

Laporan hasil RISKESDAS tahun 2010 menunjukan prevalensi kegemukan dan obesitas pada anak sekolah (6-12 tahun) secara nasional sebesar 9,2\%, sedangkan untuk propinsi Jawa Timur $(12,4 \%)$ berada di atas prevalensi nasional (Dinkes Prop. Jatim, 2010). Berdasarkan data dari RISKESDAS tahun 2013 secara nasional masalah kelebihan berat badan pada anak umur 5-12 tahun masih tinggi yaitu $18.8 \%$, terdiri dari overweight 10,8\% dan obesitas 8,8\%. (Balitbangkes Kemenkes RI, 2013)

Pencegahan dan penanggulangan kegemukan dan obesitas pada anak umumnya dan khususnya anak sekolah merupakan suatu upaya komprehensif yang melibatkan lintas 
sektor yang ada di wilayah. Komponen pertama adalah struktur dalam pemerintah untuk mendukung kebijakan dan intervensi pencegahan obesitas. Aspek struktural seperti kepemimpinan, kebijakan "kesehatan untuk semua", dana khusus untuk promosi kesehatan, sistem pemantauan penyakit tidak menular, kapasitas tenaga kerja dan jaringan kemitraan perlu memperoleh dukungan kebijakan untuk meningkatkan efektivitas program dan kegiatan intervensi berbasis masyarakat. (WHO, 2012). Kegiatan pencegahan dan penanggulangan kegemukan dan obesitas pada anak sekolah meliputi promosi, penemuan dan tatalaksana kasus yang dalam pelaksanaannya melibatkan anak, orang tua, guru, komite sekolah dan lintas sektor terkait diantaranya adalah Puskesmas. (Suiraoka, 2015). Sekolah merupakan salah satu intitusi yang mempunyai peran penting dalam memberikan pendidikan kesehatan bagi anak didiknya yang bertujuan untuk menanamkan kebiasaan hidup sehat bagi anak. Kegiatan intervensi yang dilakukan melalui beberapa program kesehatan secara intensif dan beragam dari pihak sekolah memiliki potensi yang tinggi untuk mengurangi obesitas pada anak usia sekolah. (Devinta dkk, 2016).

Kementerian Kesehatan RI menerbitkan Pedoman Pencegahan dan Penanggulangan Kegemukan dan Obesitas pada Anak Sekolah. Pedoman tersebut digunakan sebagai acuan oleh berbagai pihak meliputi pemerintah pusat, daerah, institusi sekolah, swasta dan lembaga swadaya masyarakat dalam melaksanakan pencegahan dan penanggulangan kegemukan dan obesitas pada anak. (Kemenkes, 2012).

Implementasi buku pedoman pelaksanaan pencegahan dan penanggulangan kegemukan dan obesitas di sekolah masih belum dilakukan dengan maksimal, karena fokus kegiatannya masih banyak bertumpu pada peran aktif dari puskesmas bukan dari sekolah yang bersangkutan dan belum mengatur tentang bagaimana teknis penyampaian pesan ini. Kegitan tersebut antara lain pelatihan bagi guru UKS, pembagian sesi penyampaian materi, berapa kali materi harus disampaikan kepada anak-anak, dan hal yang lainnya. (Suiaroka, 2015)

Kegiatan pencegahan dan penaggulangan obesitas ini di sekolah sangat tergantung dari peran aktif Usaha Kesehatan Sekolah (UKS). Salah satu peran UKS adalah memberikan dukungan dan motivasi agar anak melaksanakan pola hidup sehat sesuai anjuran, serta berusaha menyediakan lingkungan yang kondusif untuk anak. Program yang dilaksanakan oleh UKS adalah memberikan pengetahuan kepada siswa tentang kegemukan dan obesitas. Keluaran kegiatan ini diharapkan siswa mempunyai pengetahuan, sikap dan cara praktik yang sesuai dengan kesehatan, khususnya untuk siswa yang obesitas agar dapat merubah perilaku mereka menjadi sehat. (Devinta dkk, 2016)

Pelayanan kesehatan di sekolah dilaksanakan oleh tim kesehatan dari Puskesmas bekerjasama dengan guru dan kader kesehatan sekolah. Pelayanan kesehatan sekolah dilaksanakan secara menyeluruh (komprehensif), dengan mengutamakan kegiatan promotif dan preventif serta didukung kegiatan kuratif dan rehabilitatif untuk mencapai derajat kesehatan yang optimal. (Devinta dkk, 2016)

Salah satu contoh kegiatan preventif adalah program screening status gizi anak baru masuk sekolah yang sangat diperlukan dalam pemantauan pertumbuhan anak-anak untuk mengenali tanda-tanda awal dari gizi salah (baik gizi kurang/buruk maupun gizi lebih/obesitas). Program penilaian status gizi anak baru masuk sekolah (screening) dilaksanakan pada tataran sekolah dasar maupun sekolah menengah pertama. Hal ini sebenarnya sebuah program yang sangat baik dilakukan untuk melakukan deteksi dini pada anak dengan gangguan status gizi (baik gizi kurang/buruk maupun gizi 
lebih/obesitas). Namun sayangnya salah satu kelemahan dari program ini adalah data hasil pengukuran antropometri/penilaian status gizi yang dilakukan hanya tersimpan sebagai data statis di pihak sekolah atau petugas kesehatan saja. Deteksi dini obesitas pada anak baru masuk sekolah (ABS) juga terhenti pada sebatas skrining. Sebab terhenti pada sebatas pengukuran. Belum ada kebijakan khusus penanganan jika ditemukan anak obesitas. Hal ini tentunya memerlukan kebijakan terkait kontrol asupan makanan dan aktifitas fisik di sekolah. Dalam program screening status gizi ini pemangku kepentingan (stakeholder) dengan peran terbesar adalah Kepala Puskesmas dan Petugas Gizi Puskesmas. Selain itu keterlibatan kepala sekolah dan Guru UKS juga memegang peran yang cukup penting. (Suiraoka, 2015).

Hasil penelitian yang dilakukan Devinta dkk, 2016, di SD Negeri Lamper Kidul 02 Semarang, UKS belum memprioritaskan upaya penanggulangan obesitas pada siswanya, hal tersebut dikarenakan oleh banyak faktor antara lain tenaga pelaksana UKS yang belum melaksanakan peran dengan sebagaimana mestinya, sarana dan prasarana penunjang proses kegiatan penanggulangan obesitas yang belum lengkap. Serta masih adanya persepsi dari siswa khususnya yang obesitas bahwa UKS hanyalah wadah yang dimanfaatkan kalau siswa sedang sakit. Pengetahuan siswa terkait obesitas yang masih cukup rendah dikarenakan kurangnya informasi mengenai obesitas.

Hasil wawancara terhadap pengelola program gizi dan Usaha Kesehatan Sekolah (UKS) di tingkat Dinas Kesehatan Kota Batu dan Puskesmas Sisir Kota Batu serta guru sekolah yang bertanggung jawab dalam membina kegiatan UKS tentang pelaksanaan program pencegahan dan penanggulangan kegemukan dan obesitas di sekolah tingkat dasar belum pernah dilakukan. Sebab kegiatan ini belum menjadikan prioritas program bagi Puskesmas dan UKS. Pengetahuan kegemukan dan obesitas dan keterampilan pemantauan pertumbuhan yang dimiliki oleh guru UKS dan petugas Puskesmas masih dalam kategori kurang karena selama ini belum pernah dilakukan pelatihan tentang deteksi kegemukan dan obesitas. Pelatihan yang bertujuan untuk meningkatan pengetahuan dan keterampilan ini penting bagi petugas Kesehatan yang bertanggung jawab terhadap pelaksanaan program UKS dan guru pembina UKS dapat digunakan sebagai kegiatan pelaksanaan penemuan kasus dan pencegahan terhadap timbulnya masalah kesehatan bagi anak sekolah dasar khususnya kegemukan dan obesitas di wilayah masing-masing.

\section{METODE}

Pelaksanaan kegiatan ini dilakukan dengan beberapa tahapan meliputi: (1) Sebelum dilakukan penyuluhan terlebih dahulu diadakan pre test untuk mengetahui tingkat pengetahuan. (2) Penyampaian materi kegemukan (obesitas), penanggulangan dan pencegahan obesitas (meliputi: cara mendeteksi kejadian obesitas dengan pengukuran antropometri, aktifitas fisik yang sesuai dengan anak didik di sekolah, menyusun menu seimbang) (3) Praktek pengukuran antropometri yaitu menimbang berat badan menggunakan timbangan digital dan mengukur tinggi badan dengan mikrotoise serta menghitung Indeks Massa Tubuh (IMT) dan mengisi grafik pertumbuhan untuk menilai status gizi anak sekolah. (4) Post test untuk mengetahui tingkat pengetahuan. (5) Pendampingan di sekolah untuk membantu dalam pelaksanaan pemantauan kegemukan dan obesitas terutama dalam pengukuran antropometri dan pegisian pada buku pemantauan pertumbuhan anak sekolah. 
Alat dan bahan yang digunakan antara lain: Modul Pencegahan dan Penanggulangan Kegemukan dan Obesitas Anak Sekolah dan Buku Pemantauan Pertumbuhan Anak Sekolah, Alat Tulis, timbangan digital, mikrotoise (alat ukur tinggi badan).

Penyampaian materi tentang kegemukan (obesitas), penilaian status gizi untuk anak sekolah dasar, penanggulangan dan pencegahan obesitas dan menyusun menu seimbang. Dilakukan menggunakan metode ceramah dan diskusi dengan media power point presentation.

Pelaksanaan pelatihan yang pertama penyampaian materi tentang kegemukan (obesitas), penilaian status gizi untuk anak sekolah dasar, penanggulangan dan pencegahan obesitas dan menyusun menu seimbang.

Praktek penilaian status gizi dilakukan dengan pengukuran antropometri menggunakan timbangan digital untuk menimbang berat badan dan mikrotoise untuk mengukur tinggi badan. Praktek penimbangan berat badan dan tinggi badan dilakukan oleh semua peserta dengan bimbingan narasumber. Adapun langkah-langkah sebagai berikut:

1. Penimbangan berat badan

a. Letak timbangan di lantai yang rata

b. Angka pada display timbangan dalam posisi angka nol (0.0), setiap kali akan menimbang berat badan

c. Anak yang akan ditimbang berpakaian seminimal mungkin dan tanpa beban tambahan (sepatu, kaos kaki, topi, jaket, perhiasan, hand phone, dll), Pastikan kaki atau pakaian tidak menutupi jendela baca.

d. Anak yang ditimbang berdiri ditengah alat timbang.

e. Membaca angka pada jendela baca dan kemudian catat dalam Kilogram $(\mathrm{kg})$ dengan tingkat ketelitian $0.1 \mathrm{Kg}$

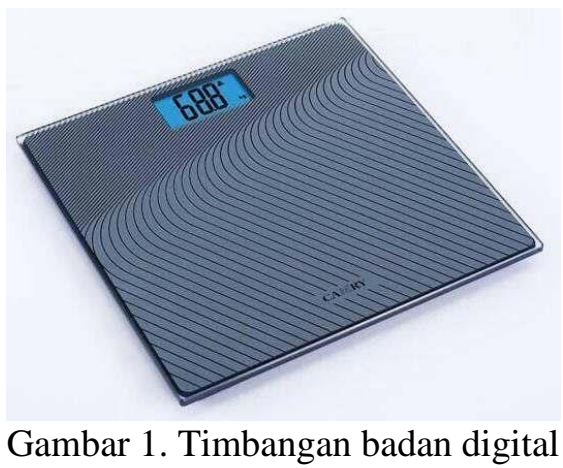

2. Pengukuran tinggi badan

a. Pastikan sepatu/alas kaki dan hiasan rambut sudah dilepas.

b. Posisikan anak berdiri tegak lurus dibawah microtoise membelakangi dinding.

c. Posisikan kepala anak berada di bawah geser microtoise dengan pandangan lurus kedepan.

d. Posisikan anak tegak bebas, bagian belakang kepala, punggung, pantat, betis dan tumit menempel kedinding. Karena posisi ini sulit dilakukan pada anak obesitas, maka tidak perlu kelima titik tersebut menempel kedinding, asalkan tulang belakang dan pinggang dalam keseimbanga (tidak membungkuk ataupun tengadah). 
e. Posisikan kedua lutut dan tumit rapat.

f. Pastikan posisi kepala sudah benar dengan mengecek garis Frankfort \{garis antara sudut mata dan telinga sejajar, berada tegak lurus pada pita).

g. Pengukur utama mengarahkan posisi kepala anak dan papan geser microtoise, sedangkan asisten pengukur membantu mengatur lutut agar menempel pada dinding.

h. Tarik kepala microtoise sampai puncak kepala anak.

i. Baca angka pada jendela baca dari arah depan dan mata pembaca sejajar garis merah.

j. Angka yang dibaca adalah yang berada pada garis merah dari angka kecil kearah angka besar.

$\mathrm{k}$. Catat hasil pengukuran tinggi badan dalam $\mathrm{cm}$ sampai $0,1 \mathrm{~cm}$.

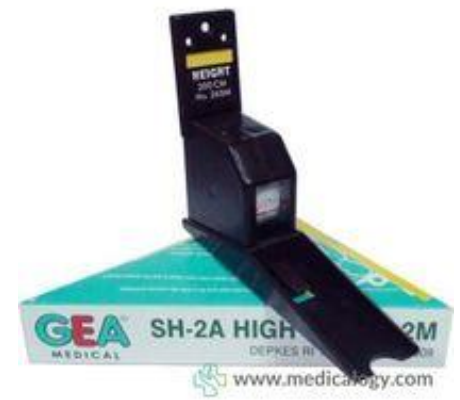

Gambar 2. Mikrotoise (Alat ukur panjang badan)

3. Menghitung Inkes Massa Tubuh

Cara menghitung IMT yang tepat, menggunakan rumus di bawah ini:

IMT = Berat badan (dalam kg) : Tinggi badan $(\text { dalam } \mathrm{m})^{2}$

4. Penentuan Status Gizi dengan Indeks Massa Tubuh Menurut Umur (IMT/U)

Sebelum mengisi grafik pertama yang harus dilakukan adalah memilih jenis Buku Pemantauan Pertumbuhan sesuai dengan jenis kelamin Biru untuk laki-laki, merah muda untuk perempuan.

a. Cara memplot IMT/U:

1) Pertama-tama tentukan umur anak pada garis horisontal. Tarik garis vertikal sesuai umur anak.

2) Tentukan angka IMT pada garis vertikal, misalnya $14 ; 14,2$; atau 14,3. Jika menggunakan kalkulator untuk menghitung IMT, hasilnya dapat dicatat dan diplot sampai 1 desimal. Tarik garis horisontal pada nilai IMT yang sesuai.

3) Plot titik pada pertemuan garis horisontal dan vertikal tersebut.

4) Lakukan pemantauan BB setiap Bulan dan lakukan evaluasi setiap 3 bulan.

b. Menentukan status gizi anak :

1) Anak disebut Kurus bila hasil ploting pada grafik dibawah garis -2 Standar Deviasi (<-2 SD) atau bila mengunakan tabel hasil perhitungan berada dibawah angka -2 Standar Deviasi $(<-2$ SD) 
2) Anak disebut Normal bila hasil ploting pada grafik di antara -2 Standard Deviasi sampai dengan +1 Standard Deviasi (-2 SD s/d 1 SD) atau bila menggunakan tabel hasil perhitungan berada dibawah angka -2 Standar Deviasi $(<-2 \mathrm{SD})$

3) Anak dikatakan Gemuk bila hasil ploting berada pada grafik diantara $1 \mathrm{SD}$ sampai 2 SD atau bila menggunakan tabel hasil perhitungan berada antara 1 dan 2 (antara 1 SD s/d 2 SD).

4) Anak dikatakan Obesitas bila hasil ploting berada pada grafik di atas $2 \mathrm{SD}$ atau bila menggunakan tabel hasil perhitungan berada di atas 2 SD (> 2 SD).

BMI-for-age CIRLS 5 to 19 years ( $z$-scores)

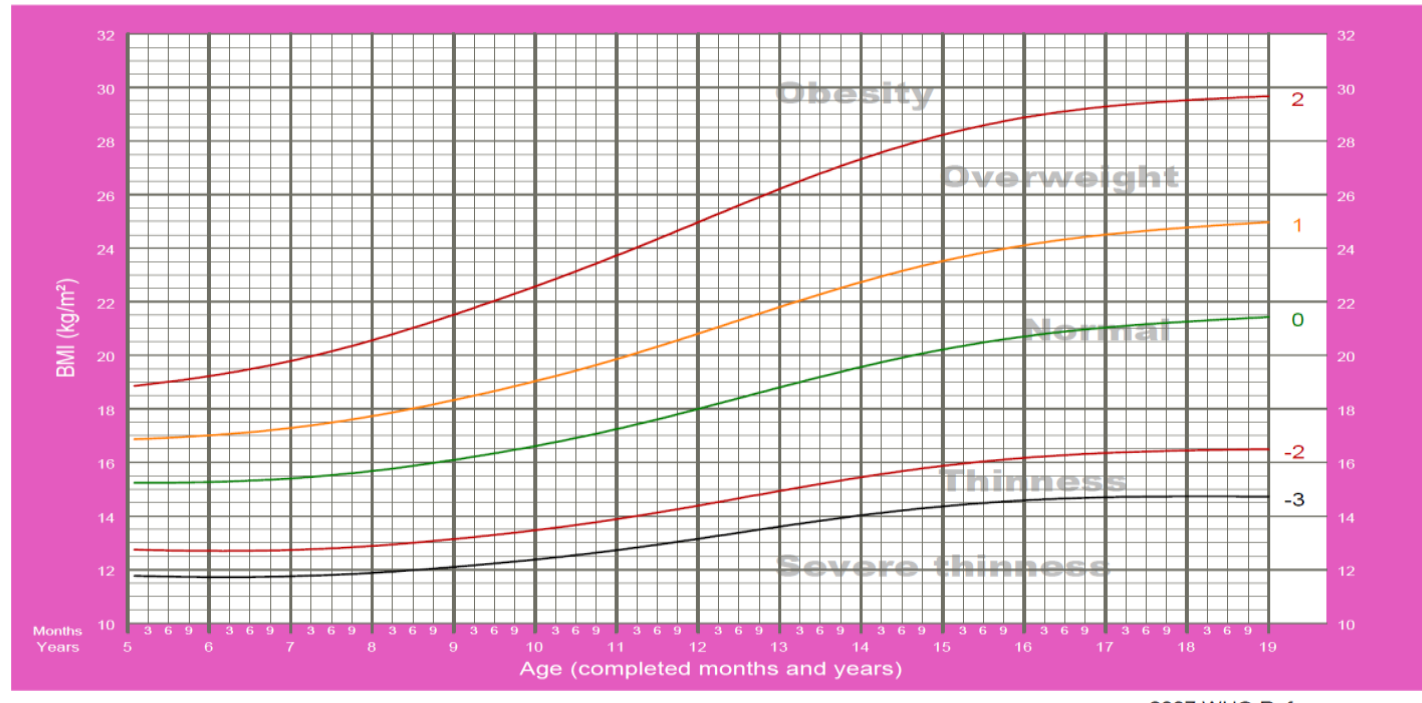

2007 WHO Reference

Gambar 3. Grafik IMT/U Perempuan 


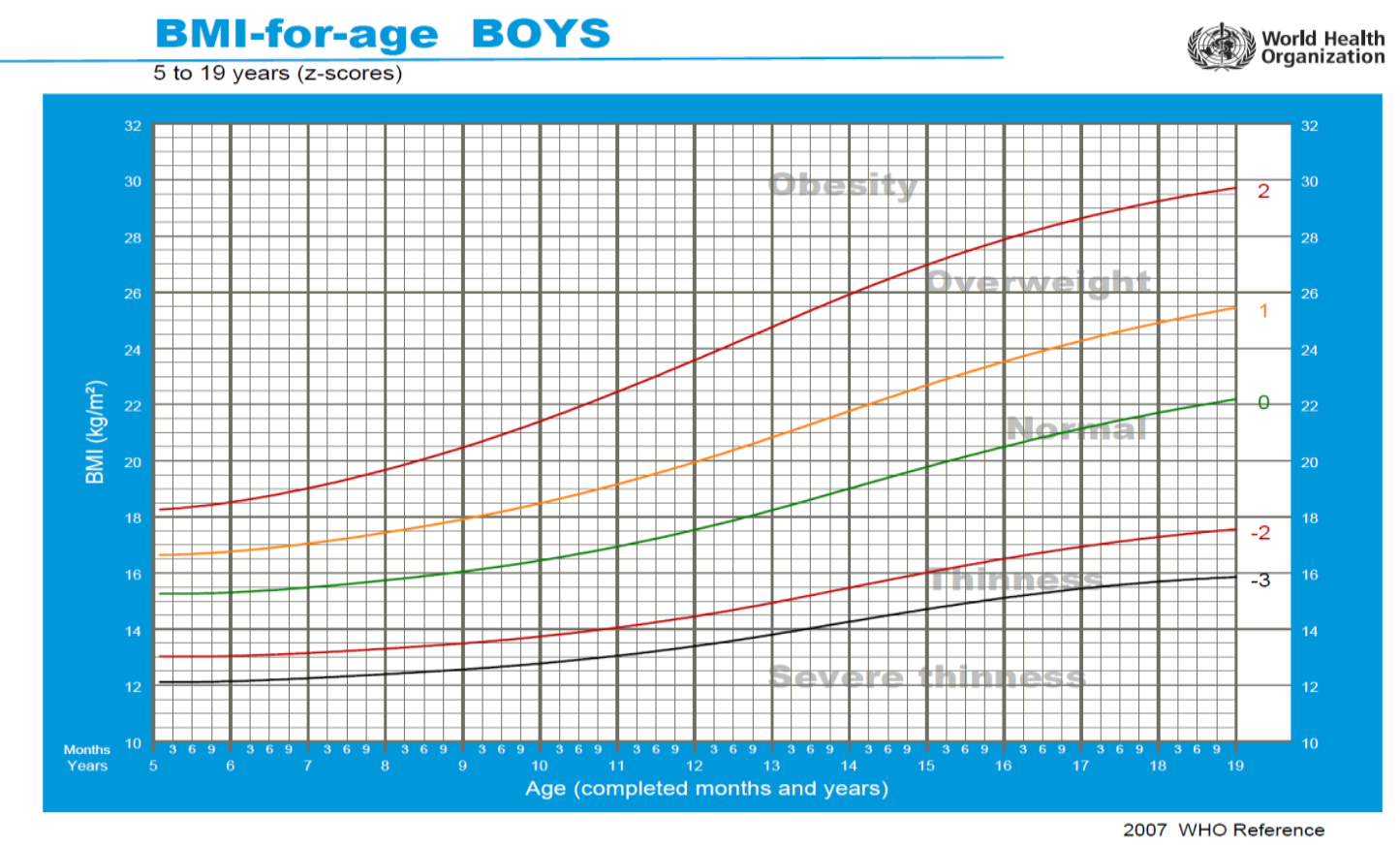

Gambar 4. Grafik IMT/U Laki-laki

5. Pendampingan di sekolah untuk membantu dalam pelaksanaan pemantauan kegemukan dan obesitas terutama dalam pengukuran antropometri dan pengisian pada buku pemantauan pertumbuhan anak sekolah. Sebagai kelanjutan kegiatan pelatihan pemantauan status gizi dan pencegahan dan penanggulangan sekolah dan juga bagi sekolah yang terpilih diberikan bantuan alat antropometri (timbangan digital dan mikrotoise) dan buku pemantauan pertumbuhan anak sekolah supaya dapat digunakan untuk kegiatan pencegahan kegemukan dan obesitas di sekolah.

\section{HASIL KARYA UTAMA DAN PEMBAHASAN}

Pelatihan Pencegahan dan Obesitas bagi Petugas Penanggung Jawab Program UKS di Puskesmas dan Guru Pembina UKS yang dilaksanakan di Puskesmas Sisir diikuti oleh 17 peserta yang terdiri dari : 1 orang pemegang program gizi di Dinas Kesehatan; 5 orang pemegang program gizi di tingkat Puskesmas, 5 orang penanggung jawab program UKS di Puskesmas meliputi Puskesmas Sisir, Batu, Junrejo, Bumiaji, Beji; 6 orang guru UKS terdiri dari SDN Temas 1, SDN Sisir 1, SDN Sidomulyo 1.

Pelatihan pencegahan kegemukan dan obesitas tersebut terlebih dahulu diawali dengan pre-test untuk mengetahui pengetahuan peserta terhadap pencegahan dan penanggulangan kejadian obesitas. Metode yang digunakan dalam penyuluhan ini dengan ceramah dan diskusi bertujuan untuk meningkatkan pengetahuan, sedangkan simulasi dan demonstrasi serta praktek untuk meningkatkan keterampilan dalam pengukuran tinggi badan dan berat badan serta menghitung Indeks Massa Tubuh (IMT) untuk mengetahui status gizi anak.

Materi yang diberikan meliputi materi dasar tentang Pencegahan Kegemukan dan Obesitas pada Anak Sekolah, Materi Inti 1: Deteksi Dini, Penemuan dan Tindak Lanjut Kasus Kegemukan dan Obesitas pada Anak Sekolah, Materi Inti 2: Pelaksanaan 
Kegiatan Pencegahan Kegemukan dan Obesitas pada Anak Sekolah. Setelah dilakukan penyampaian materi dilaksanakan pos-test untuk mengetahui pengetahuan tentang kegemukan dan obesitas yang sudah diberikan. Penyampaian Materi dengan metoda ceramah dan tanya jawab disampaikan dengan menggunakan media powerpoint presentation, selain itu juga peserta diberikan buku modul dan buku pemantauan pertumbuhan untuk anak sekolah. Pada saat penyampaian materi semua peserta cukup respon pada materi yang diberikan karena materi ini jarang diberikan padahal merupakan bahan untuk pelaksanaan program UKS.

Hasil pre-test menunjukkan rata-rata nilai pengetahuan gizi sebesar 51,7 dengan nilai terendah 20 dan yang tertinggi sebesar 90. Setelah dilakukan pos-test diperoleh nilai rata-rata pengetahuan gizi sebesar 83,5 dengan nilai terendah 70 dan yang tertinggi 90. Hal ini menunjukkan ada peningkatan pengetahuan sebelum dan sesudah diberikan penyuluhan.

Pengetahuan peserta tentang kegemukan dan obesitas saat sebelum pemberian materi menunjukkan perbedaan nilai yang cukup jauh. Hal ini dikarena beberapa peserta merupakan guru UKS dan tenaga kesehatan yang baru memegang program UKS dan juga belum pernah mengikuti kegiatan yang seperti ini. Sedangkan peserta yang mempunyai nilai tinggi dikarenakan pemegang program gizi yang bertanggung jawab pada pencegahan dan penanggulangan masalah-masalah gizi (kegemukan dan obesitas).

Peningkatan pengetahuan yang dicapai oleh peserta menunjukkan bahwa materi yang disampaikan oleh narasumber mudah diserap dan dipahami. Beberapa peserta berpendapat bahwa materi yang diberikan sesuai dengan program yang akan dibuat dalam rangka kegiatan UKS di sekolah dan juga di Puskesmas akan menduplikasi kegiatan tersebut. Supaya mudah dalam melakukan kegiatan yang serupa baik di Sekolah maupun Puskesmas semua peserta dibekali Modul Pelatihan Pencegahan Kegemukan dan Obesitas pada Anak Sekolah.

Kegiatan praktek yang dilakukan oleh semua perserta adalah mengukur tinggi badan, berat badan dan pengisian buku pemantauan pertumbuhan. Pengukuran tinggi badan menggunakan alat mikrotoise, sedangkan untuk berat badan dengan menggunakan timbangan digital dan untuk mengetahui status gizi anak sekolah dengan indeks IMT/U menggunakan buku pemantauan pertumbuhan.

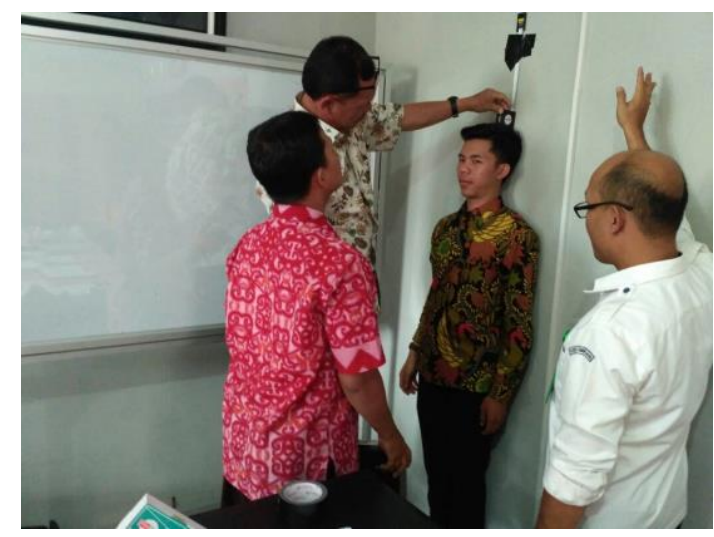

Gambar 5. Praktek Pengukuran Tinggi Badan 


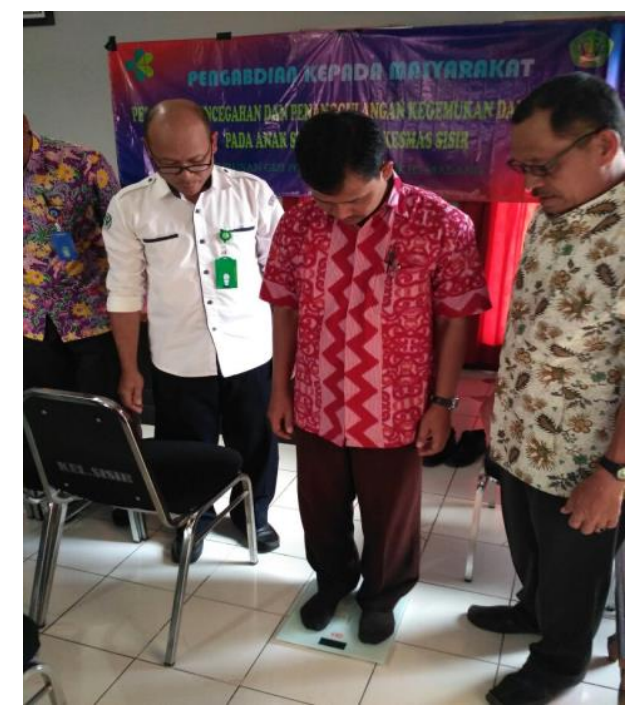

Gambar 6. Praktek Penimbangan Berat Badan

Sebelum dilakukan praktek pengukuran panjang badan dilakukan demonstrasi terlebih dahulu oleh narasumber. Hasil diskusi dengan memberikan beberapa pertanyaan cara melakukan pengukuran mulai dari persiapan sampai dengan pencatatan hasil diketahui masih ada beberapa peserta yang belum tepat dalam melakukan pengukuran. Khusus peserta dari guru UKS belum pernah melakukan pengukuran di sekolah masingmasing disebabkan tidak mempunyai alat dan alatnya sudah rusak. Hal-hal yang kurang diperhatikan dalam mempersiapkan atau memasang alat (mikrotoise) masih kurang tepat. Sebab jika salah memasang alat maka akan menyebabkan hasil pengukuran yang tidak tepat. Selain itu juga dalam melakukan pengukuran belum mengetahui langkahlangkah yang benar. Setelah diberikan contoh dengan melakukan demonstrasi semua perserta mencoba melakukan pengukuran. Keterampilan peserta pada saat praktek pengukuran tinggi badan menggunakan mikrotoise menunjukkan bahwa pada saat pertama kali menggunakan alat sebagian besar peserta masih banyak yang belum tepat. Langkah-langkah dalam pengukuran yang kurang tepat tersebut adalah tumit dan mikrotoise tidak menempel pada dinding saat pengukuran. Akan tetapi dengan arahan dan bimbingan narasumber pada akhirnya dapat mengukur tinggi badan dengan benar.

Praktek penimbangan berat badan lebih lancar dalam pelaksanaannya. Hasil observari perserta pada saat praktek penimbangan berat badan, peserta tidak banyak mengalami kesulitan dalam melakukannya. Hal ini dikarenakan alat yang digunakan sangat mudah untuk mengopesaikannya karena menggunakan timbangan digital dan hasilnya dapat menunjukkan angka angka yang sesungguhnya dengan tingkat ketelitian $0,1 \mathrm{~kg}$. Akan tetapi pada saat penimbanagan masih ada yang belum memperhatikan halhal yang akan mempengaruhi hasil penimbangan. Hal ini terjadi karena kebiasaan melakukan penimbangan menggunakan timbangan injak (bathroom scale) yang tingkat ketelitian hasilnya $1 \mathrm{~kg}$. Kesalahan dalam praktek penimbangan yang dilakukan adalah tidak meminta kepada orang yang ditimbang untuk mengeluarkan barang-barang dari kantong baju dan celana, contohnya kunci, handphone. Narasumber selalu mengingatkan dan membimbing dengan sekama sehingga kesalahan yang dilakukan oleh peserta yang lain tidak diulangi lagi.

Praktek penilaian status gizi IMT/U merupakan kegiatan untuk mengetahui status gizi anak sekolah apakah mempunyai status gizi baik atau tidak. Semua perserta baru 
pertama kali melakukan penilaian status gizi ini dengan menggunakan Buku Penilaian Staus Gizi Anak Sekolah. Pengisian ini dengan cara simulasi kasus yang kemudia dinilai status gizinya. Pada awalnya beberapa peserta masih belum mengerti cara pengisiannya, tetapi dengan bimbingan mereka dengan mudah melakukannya. Pendapat beberapa perserta kegiatan ini merupakan hal yang baru karena selama ini kegiatan pengukuran penimbangan disekolah hanya dicatat saja. Praktek ini secara langsung dapat menilai status gizi serta kesehatan masing-masing siswa dengan mengetahuinya tersebut sehingga akan dapat menentukan langkah-langkah yang akan diambil tindakan untuk mengatasi permasalahan yang ditemukan sedini mungkin.

Pada akhir kegiatan dilanjutkan pembahasan rencana tindak lanjut. Rencana tindak lanjut yang telah disepakati adalah masing-masing sekolah akan melakukan pemantauan/deteksi kegemukan dan obesitas khususnya pada siswa kelas 1 dan sosialisasi terhadap guru yang lainnya maksimal 2 minggu setelah pelatihan.

Kegiatan pendampingan pasca pelatihan dilakukan di 3 sekolah meliputi: SDN Temas 1, SDN Sisir 1 dan SDN Sidomulyo 1. Implementasi hasil Pelatihan Pencegahan dan Penanggulangan kegemukan dan obesitas di sekolah sebaiknya dilakukan pendampingan dalam pelaksanaanya. Karena kegiatan ini merupakan salah satu bentuk evaluasi untuk mengetahui materi yang diberikan dan praktek yang dilakukan sudah dilaksanakan dengan benar sesuai dengan yang diajarkan.

Pada saat pendampingan di sekolah sebagai langkah tindak lanjut kegiatan pasca pelatihan diperoleh hasil masing-masing sekolah telah melakukan sosialisasi Pencegahan Kegemukan dan Obesitas kepada guru yang lainnya. Dari ketiga sekolah yang telah dilakukan pendampingan hanya SDN Temas 1 yang sudah melakukan deteksi kegemukan dan obesitas dengan melakukan pengukuran antropometri meliputi tinggi badan dan berat badan pada saat mata pelajaran olah raga dan kegiatan UKS. Hasil pengukuran tersebut masih belum diolah dan dinterpretasikan status gizi masing-masing siswa dikarenakan membutuhkan waktu yang cukup lama untuk menghitung dan memasukkan dalam grafiknya sehingga tidak diketahui berapa siswa yang mempunyai masalah kesehatan (masalah gizi). Kendala yang dihadapi pada saat kegiatan pemantauan pertumbuhan yang seharusnya didampingi oleh petugas Puskesmas . Tetapi pada saat kegiatan berlangsung tidak dapat didampingi dikarenakan jadwal petugas yang pada saat kegiatan ada tugas lain. Untuk mengatasi permasalahan tersebut sebaiknya melakukan koordinasi bersama kapan akan melaksanakan kegiatan tersebut.

Sedangkan 2 sekolah yang lainnya belum melakukan kegiatan deteksi kegemukan dan obesitas tetapi sudah merencanakan kegiatan tersebut. Permasalahan yang ditemukan pada sekolah yang belum melakukan kegiatan tersebut dikarenakan kesibukan guru penanggungjawab UKS dan sekolah sedang mempersiapkan siswanya dalam mengikuti kegiatan lomba.

\section{KESIMPULAN}

Pencegahan dan penanggulangan kegemukan dan obesitas pada anak tidak bisa dilakukan oleh sektor kesehatan saja namun peran serta lintas sektor (sektor pendidikan) sangatlah penting. Berdasarkan diskusi yang dilakukan saat penyampaian materi berlangsung bahwa materi yang diberikan sangat bermanfaat dan ada sebagian merupakan hal yang baru sehingga dapat digunakan untuk mengembangkan program pencegahan dan penanggulangan kegemukan dan obesitas khususnya pada anak sekolah.

Metode Pelatihan dengan ceramah, demonstrasi dan praktek menunjukkan pengetahuan gizi peserta sebelum dan sesudah diberikan pelatihan meningkat dari nilai 
rata-rata 51,7 menjadi 83,5 . Hasil pengamatan akhir yang telah dilakukan pada saat praktek pengukuran tinggi badan dan berat badan menunjukkan bahwa peserta sudah terampil dalam penggunaan alat antropometri yang sesuai dengan langkah-langkah pengukuran berat badan maupun tinggi badan dan juga dapat menginterpretasikan status gizinya.

Pelaksanaan deteksi kegemukan dan obesitas dengan model pendampingan dari petugas kesehatan Puskesmas perlu dilanjutkan untuk meningkatkan pengetahuan gizi dan keterampilan antropometri dan analisis hasil pengukuran. Untuk lebih mengefektifkan kegiatan deteksi kegemukan dan obesitas di sekolah tidak hanya dilakukan oleh guru dan petugas puskesmas sebagai penanggung jawab kegiatan UKS, tetapi melatih siswa dalam hal ini Kader UKS (kader tiwisada) juga dapat melakukan kegiatan ini supaya dapat melaksanakannya secara mandiri.

\section{DAFTAR PUSTAKA}

Andy Japutra, Eddy Fadlyana, Anggraini Alam, 2015. Risk Factors for Obesity in 6 to 12-Year-Old Children. Paediatrica Indonesiana, Vol. 55, No. 1, January 2015. 3539

Badan Penelitian dan Pengembangan Kesehatan, Kementerian Kesehatan RI, 2013. Riset Kesehatan Dasar 2013. Jakarta.

Devinta Very Fridayanti, Galuh Nita Prameswari, 2016. Peran UKS (Usaha Kesehatan Sekolah) Dalam Upaya Penanggulangan Obesitas Pada Anak Usia Sekolah. Journal of Health Education 1 (2). 8-14.

Dinas Kesehatan Propinsi Jawa Timur, 2010. Laporan Profil Dinas Kesehatan Propinsi Jawa Timur. Dinkes Prop Jatim, Surabaya.

I Putu Suiraoka, 2015. Pencegahan Dan Pengendalian Obesitas Pada Anak Sekolah. Jurnal Ilmu Gizi Volume 6 Nomor 1 Februari 2015: 33 - 42

Kementerian Kesehatan RI. Direktorat Jenderal Bina Gizi dan Kesehatan Ibu dan Anak. 2012. Pedoman Pencegahan dan Penanggulangan Kegemukan dan Obesitas pada Anak Sekolah. Jakarta

Kementerian Kesehatan RI, 2013. Pedoman Penyelenggaraan Pelatihan Pencegahan dan Penanggulangan Kegemukan dan Obesitas pada Anak Sekolah. Jakarta

Sri Poedji Hastoety Djaiman, Sihadi, Kencana Sari, Nunik Kusumawardani, 2017. Meta analisis: Pencegahan Obesitas pada Anak Sekolah. Media Litbangkes, Vol. 27 No. 1, Maret 2017. $39-48$

World Health Organization (WHO), 2012. Population Based Approaches to Childhood Obesity Prevention. Geneva, Switzerland 